DOI :

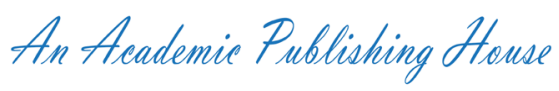

\title{
Relationships among Loyalty, Image, Satisfaction and Intention Mediated by Trust
}

\author{
Lerbin R. Aritonang R.
}

Faculty of Economics, Tarumanagara University, Jakarta, Indonesia.

\begin{abstract}
Purpose: The objective of this research is to test the mediation role of trust among loyalty, image and satisfaction with the intention to make customers to use bank services in the future.
\end{abstract}

Design/Methodology/Approach: Data were collected from traditional banks' customers. The research uses a structural equation modelling, using LISREL 8.80.

Findings: The findings show trust has a partial mediating effect on relationships among loyalty, image and satisfaction with intention. Total, direct and indirect effects of loyalty on intention are positive and significant. Total and indirect effects of image and satisfaction on intention are positive and significant. The direct effects of image and satisfaction on intention are positive but not significant. The indirect effects of image and satisfaction on intention are greater than the direct effects of image and satisfaction on intention.

Practical Implications: The research provides an insight to the Indonesian banking sector and the interrelationships among loyalty, image, satisfaction and trust to enhance customers' intention to repurchase banks' services in the future. Service policy makers should invest in trust, loyalty, image and satisfaction to enhance customers' intention to repurchase.

Originality/Value: Examination of the indirect effects of image - through trust - on intention contributes more value by understanding the indirect effects of image on increased intention.

KEYWORDS: Intention, Loyalty, Image, Satisfaction, Trust, Bank

\section{INTRODUCTION}

Loyalty, i.e. repurchasing the same products, is a main topic in consumer behavior researches. It is because corporations get profits by the loyalty (Richheld and Sasser, 1990; Jones and Taylor, 2007; Zeithaml, 2000).

From the perspective of time, loyalty is related to an event in the past. So, the relevant variable for a future time is a variable that can be used to explain and predict loyalty. A frequent and dominant variable used to explain and predict consumer loyalty is intention. Theory of Reasoned Action (Fishbein and Ajzen, 1975) and Theory of Planned Behavior (Ajzen, 1991) are the two theories frequently referred to explain a direct relationship between intention and loyalty of consumers. The external validity of the two theories have been empirically tested in a broad range sciences, including consumer behavior.

According to Reicheld and Sasser (1990), the image of a company is an important tool to support the company in a competitive situation and to develop its profitability. In general, the corporate image is an asset that can be used to maximize market share, profit, acquisition of new customers, maintain existing customers, neutralize actions of competitors (Fombrun and Shanley, 1990; Bravo, Montaner and Pina, 2009) and has a dominant impact on the consumers' decision to consume (Zhang, 2015).

In banking context, researches about image and intention are still rarely performed as presented in Table 1, i.e. only three of twelve researches. Cengíz, Ayyildiz, and Bünyamin ER (2007) and Bravo, Montaner and Pina (2012) implicitly stated that there was an indirect effect between image and intention. Unfortunately, they had no hypothesis and analysis about the indirect effect. In another one, Maiyaki (2013) found that the relationship between image and intention is moderated by individualism.

The specific objective of this research is to develop a behavioral intention model in banking context using 
customers' intention to repurchase as a consequence. This research may be the first research about the mediating role of trust between image and intention in banking context. Thus, this research is important to provide additional information

Table 1. Researches about Bank Intention

\begin{tabular}{|l|l|}
\hline \multicolumn{1}{|c|}{ Researchers (Year) } & \multicolumn{1}{c|}{ Explanation Variables } \\
\hline Arora (1996) & Price and variety of services \\
\hline Page and Luding (2003) & An attitude toward direct marketing media and customer demography \\
\hline $\begin{array}{l}\text { Cengíz, Ayyildiz and } \\
\text { Bünyamin ER (2007) }\end{array}$ & Image, efficiency of advertising, perceived quality, expectation, perceived value, complaint \\
\hline Puschel and Mazzon (2010) & An attitude toward behavior, subjective norm, behavioral control and customer status \\
\hline $\begin{array}{l}\text { Bravo, Montaner and Pina } \\
\text { (2012) }\end{array}$ & Corporate brand image and global attitude \\
\hline $\begin{array}{l}\text { Hoffmann, Franken and } \\
\text { Broekhuizen (2012) }\end{array}$ & $\begin{array}{l}\text { Innovation, service quality and relative importance of innovation, relationship quality } \\
\text { (satisfaction and trust) }\end{array}$ \\
\hline Maiyaki (2013) & Individualism, technique and functional quality, corporate value and image \\
\hline Tsai, Chien and Tsai (2014) & Benefit, compatibility, satisfaction, customer skill \\
\hline Aritonang R. (2015) & Loyalty and trust \\
\hline Liu (2015) & Service quality, value, satisfaction, trust \\
\hline Topcu (2015) & Loyalty \\
\hline Aritonang R. (2016) & Satisfaction, trust, loyalty \\
\hline
\end{tabular}

\section{THEORITICAL BACKGROUND AND HYPOTHESES DEVELOPMENT}

\section{Intention}

According to Ajzen (1991), "Intentions are assumed to capture the motivational factors that influence a behavior; they are indications of how hard people are willing to try, of how much of an effort they are planning to exert, in order to perform the behavior." (p. 181) So, intention is a motivation that directs a person's behavior. Intention is indicated by the strength of one's desire to perform an action. In addition, intention is also indicated by the intensive plan to realize the desire in the future. Accordingly, Fishbein and Ajzen (1975) stated that the intensity of the intentions are manifested in a subjective probability of person to perform a behavior.

\section{Trust}

Rotter (1967) defines trust as “ . . . an expectancy held by an individual or group that the word, promise, verbal or written statement of another individual or group can be relied upon." (p. 651) Thus, trust includes two different parties, i.e. someone who believes and the one who is believed. In addition, trust orients to the expectation that will happen in the future. Objects of the expectation itself may be either verbal or written promises that the believed party will realize the promises in the future. A similar definition of trust was also formulated by Moorman, Zaltman and Deshpande (1992) as follows: "Trust is defined as the willingness to Rely on an exchange partner in whom one has confidence." (p. 316) for researchers and practitioners about the role of image to explain the intentions of bank customers. Accordingly, other antecedent variables of this research are loyalty and satisfaction.
Trust will be realized if someone who believes has confidence about the reliability and integrity of those who believed (Morgan and Hunt, 1994; Garbarino and Johnson, 1999). According to the expected result of trust, Anderson and Narus (1990) stated that the expectation includes believed party's actions that give positive results without negative results. Sheth and Mittal (2004) also stated that trust is a desire or willingness of the party to believe the ability, integrity and motivation of the believed party to explicitly or implicitly realizes his/her promises.

Based on the above descriptions it can be seen that trust is the expectation of those who believe that the believed party has the ability, integrity and motivation to realize its promise implicitly or explicitly as expressed in a way that does not undermine the party.

\section{Loyalty}

Perspective of consumer loyalty in this research is an overt behavior. Accordingly, Neal (1998) stated that consumer loyalty is a behavior, not an attitude. Neal (1999) also stated that "Customer loyalty is the proportion of times a purchaser chooses the same product or service in a specific category compared to the total number of purchases made by the purchaser in that category, under the condition that other acceptable products or services are conveniently available in that category." (p. 21) Neal (2000) further stated that there are three implications of the definition. One, the degree of consumer loyalty may be expressed in terms of proportion and ranging from $0 \%$ to $100 \%$. Two, consumer loyalty is the behavior of individuals or groups based on their buying 
behavior or choose to buy. Three, the size of consumer loyalty is limited to specific categories of products that are functionally be replaced. With another statement, the consumer should have some substitutive products.

The Neal' opinion refers to operational definition or measure of customer loyalty. Accordingly, consumer loyalty in this research is conceptually defined as buying behavior and / or repeatedly consume the same product from a variety of substitutive products. So, consumers declare their loyalty to a product (goods, services or a combination of both) if they has purchased and / or consumed it more than once. In addition, consumers states their loyalty to a product if they have some substitutive product. Thus, consumers may have loyalty on two or more products.

\section{Image}

A brand image variable consists of image and brand. The image may be defined as "contents of consciousness that possess sensory qualities as opposed to reviews those that are purely verbal or abstract" (Hackmann, 1998: 301). So, the image is a quality of senses about something. The image is a result of "a process (not a structure) by which sensory information is represented in the working memory" (MacInnis and Price, 1987 in Stern, Zinkin and Holbrook, 2002). Thus, the image is a result of a perception process about information senses.

Reynolds (1965) stated that "an image is the mental construct developed by the consumer on the basis of a few selected impressions among the flood of the total impressions; it comes into being through a creative process in which these selected impressions are elaborated, embellished, and ordered" ( $\mathrm{p}$. 69) It means that people face a lot of impressions about the stimulus but only a certain impression attracts him. So, the image is understood as a gestalt concept (Kunkel and Berry, 1968). The image may be also stated as "the set of beliefs, ideas, and impressions that a person holds regarding an object" (Kotler, 2001 in Sondoh Jr., Omar, Wahid, Ismail and Aaron, 2007). It means that the image may be beliefs, ideas, and impressions of people about a stimulus.

According to Nanand (2005), a brand is a symbol in people's minds and the symbols can be illustrated as a name or a symbol that may differentiate the product from competitors' products. However, AMA (American Marketing Association, 2007) states that "A brand is a term, design, name, symbol or any other feature that distinguishes one company's product from others'" It means that the brand is associated with each feature that distinguishes something from others. Thus, a name is not the same as the brand. A name is only one feature of the brand.

According to Biel (1992), an image is "a cluster of attributes and associations that connect consumers to the brand name" (p. 8). Thus, the image of a brand is a group of attributes that associate consumers with a product. Keller (1993) also stated that a brand is "a set of perceptions about a brand as reflected by the brand associations in the consumer's memory." (p. 3) Thus, a brand image is a perception that is reflected through associations with a brand in one's memory.

Accordingly, Aaker (1991) stated that brand image is a set of brand associations which is everything that is associated in memory. According to Kotler and Armstrong (1996), brand image is the belief that people have about a brand. Campbell (1993) also stated that the image is associated with people's perception, besides belief, about a brand.

So, brand image is a belief that people have about a brand. The belief is associated with brand's features. The brand itself can be anything that is attached to something.

\section{Satisfaction}

Consumer satisfaction or dissatisfaction of a product occurs after she/he buys and/or consumes a product, goods or services or a combination of both. People buy and consume a product to meet their needs or whim. People have expectation from consuming a product. If the expectations are not met, then they will be dissatisfied. Conversely, if the expectations are met or exceeded then they will be satisfied. Thus, satisfaction is a result of a comparison between the expectations before purchasing and consuming a product against the actual results. The concept of satisfaction and dissatisfaction refers to an expectation disconfirmation model that has consistently validated through empirical researches (Engel, Blackwell, and Miniard, 1995).

In the above description, consumers buy with the expectation of how a product will actually perform while the product is consumed, and the results may be classified in one of three groups. One, the performance is appropriate, i.e. normative judgments that reflect the performance of a product should be obtained with certain costs and efforts used to obtain and use the product (Cadotte, Woodruff and Jenkins, 1987). Two, the ideal performance, i.e. the level of optimum performance or expectation will be "ideal" (Holbrook, 1982). Three, the expected performance, i.e. what was probably to be expected (Leichty and Churchill, Jr. in Engel, Blackwell, and Miniard, 1995).

Satisfaction object itself can be a product as a totality or attributes (Oliver, 1997; Hill and Alexander, 2000; Wells and Prensky, 1996; Gryna, 2001; Loudon and Bitta, 1993). Satisfaction also relates to all things about acquisition and consuming a product, such as the physical facilities, the atmosphere, and others.

\section{Trust and Intention}

The Theory of Reasoned Action and Theory of Planned Behavior stated that the intention of someone to do something begins with the belief that it is possible to do the behavior (Fishbein and Ajzen, 1975; Ajzen, 1991). Trust of consumer in the competence, reliability and integrity of producer will 
determine consumer intention to repurchase the products in the future (Cyr, Hassanein, Head and Ivanov, 2007; Zeithaml, Berry and Parasuraman, 1996; Aritonang R., 2015, 2016).

Some researches about relationship between trust and intention have been done (Chinomona and Sandada, 2013; dos Santos and Basso, 2012; Herbst, Hannah and Allan, 2013; Liu, 2015; Mahmoudzadeh, Bakhshanden and Ilkhechi, 2013; Shainesh, 2012; Aritonang R., 2015; Topcu and Duygun, 2015). The results of the researches show that trust is a positive and significant predictor to the consumer intention to repurchase the same product.

The above theoretical base and the researches suggest that the consumer intention to be loyal to a product shows an intention to repurchase the same product in the future. The intention may be related to the consumer trust in the product. The higher the consumer trust in the product, the higher the consumer intention to repurchase the product in the future. Accordingly, a hypothesis (H1) can be formulated as trust is a positive predictor of intention.

\section{Loyalty and intention}

Once the consumer loyalty to a brand increases, he/she will be less responsive to competitors' actions. He/she will commit to the brand and he/she is willing to pay a higher price and will promote the brand (Upamannyu, Gulati and Mathur, 2014). Accordingly, the intention to choose a brand is one of the main outcomes of loyalty towards the brand (Aaker and Joachimsthaler, 2000). A positive consumer experience on a brand will make him loyal to the brand, and he would choose the brand in the future (Oliver, 1999).

There are several researches about the role of loyalty to explain customer intention to buy the same product again (Chinomona and Sandada, 2013; Fandos and Flavian, 2006; Hsin, Huery and Yes, 2009; Schoenbachler, Gordon and Aurand, 2004; Aritonang R., 2015 , 2016). The results of the researches support that loyalty is a positive predictor of the intention to repurchase the same product.

The above theoretical base and the researches suggest that loyal consumers had experiences about the same product. The consumers' intention itself is the intentions to repurchase the same products in the future. The consumers' experiences will determine their intention to repurchase the product in the future. The more often a consumer buys a product in the past indicates that the product can meet his/her needs. Based on such a framework, hypothesis two (H2) can be formulated that loyalty is a positive predictor of intention.

\section{Image and Intention}

Brand image is a positive predictor of the intentions (Zeithaml, 1988; Selnes, 1993; Zins, 2001; Cretu and Brodie, 2007). It was empirically tested in researches conducted by Thakur and Singh (2012) and Che-Hui, Miin-Jye, Li-Ching and Kuo-Lung (2015). Nevertheless, Cretu and Brodie (2007) showed a positive but not significant relationship between image and intention. Another research conducted by Sondoh Jr., Omar, Wahid, Ismail, Isaac and Aaron (2007) showed that only partially dimensional image brand positively and significantly associates with intention.

In the banking context, Cengiz, Ayyildiz, and Bunyamin ER (2007) showed that there is a positive and significant relationship between bank image and customer intention to use the services of banks. Another research conducted by Maiyaki (2013) showed that a bank's image is a positive but not significant predictor of the customers' intention to use the services of the banks.

The above theoretical base and the researches suggest that brand image is a customer's belief regarding to a bank. The strength of consumer trust in a bank will be able to improve his or her intention to use the services of the bank in the future. Based on such a framework, hypothesis three (H3) can be formulated that the brand image is a positive predictor of the intention.

\section{Satisfaction and Intention}

Satisfaction is one form of consumer experiences. Consistent with the above explanations, a positive experience will increase consumer intention to use a product (Allen, Machleit and Kleine, 1992; Oliver, 1993; Richins, 1997; Barsky and Nash, 2002). Accordingly, several researches have found that satisfaction is a positive predictor of intention (Martin, O'Neil, Hubbard and Palmer, 2008; Deng, Turner and Prince, 2010; Rejikumar and Ravindran, 2012; Thakur and Singh, 2012; Lee , Trail, Lee and Schoenstedt, 2013; Keng and Liao, 2009; Aritonang R., 2016). In a bank context, Bravo, Montaner and Pina (2009) also showed that satisfaction is a positive and significant predictor on intentions.

Based on the above theoretical base and the researches may be known that customer satisfaction about a product happens in the past. The higher the customer satisfaction when consuming the product the more likely he/she will buy it in the future. Based on such a framework can be formulated hypothesis four (H4) that satisfaction is a positive predictor of intention.

\section{Loyalty and Trust}

Trust is a key element for continued relationship. Both parties in trust context would have a tendency to maintain the relationship if there is mutual trust between them. Trust is an intrinsic feature of each valued social relationships (Tsiotsou, 2013). Trust in a brand is an important construct in marketing because the trust will generate a positive attitude which can further generate commitment to the brand (Delgado-Ballester and Munuera-Aleman, 2001).

In general, the results of research about relationship between trust and loyalty are positive. The higher the consumer trust in the other party or a brand, he is more loyal to the other party or the brand (Anuwichanont, 2011; Ball, Coelho and Machas, 2004; Benachenhouand and Benhabib, 2013; Caceres 
and Paparoidamis, 2007; Carter, Wright, Thatcher and Klein, 2014; Casalo, Flavian and Guinaliu, 2007; Chinomona and Sandada, 2013; Geok and Sook, 1999; Horppu, Kuivalainen, Tarkiainen and Ellonen, 2008; Matzler, Grabner-Krauter and Bidmon, 2006; Ramaseshan, Rabbanee and Hui , 2013; Sharifi and Esfiandi, 2014; Singh, Iglesis and Batista-Foguet, 2012; Sumaedi, et al., 2014; Tsiotsou, 2013; Upamannyu, Gulati and Mathur, 2014). In the context of banks, Kim and Ghantous (2013) and Aritonang R. $(2015,2016)$ also found that trust is a positive predictor of loyalty.

The above theoretical base and the research suggest that trust orients to the future. A customer's trust itself is inseparable from his/her experience of the product, either directly through the purchase and consumption as well as through other sources. A customer may have the experiences when he/she repurchases and re-consumes a product, i.e. consumer loyalty to the product. Based on such a framework hypothesis five (H5) can be formulated that loyalty is a positive predictor of trust.

\section{Image and Trust}

There are two researches about relationship between image and trust. Achmad (2014) showed that image and trust have a positive and significant relationship. A research conducted by Che-Hui, Miin-Jye, Li-Ching and Kuo-Lung (2015) also showed that image and trust have a positive and significant relationship.

From the above theoretical basis and researches, it can be seen that image represents the customer confidence about the features inherent in a bank.
Customers who believe a bank's features would trust the bank as a means to meet their need for bank services. Based on such a framework, hypothesis six (H6) can be formulated that the bank's image is a positive predictor of trust.

\section{Satisfaction and Trust}

Experiencing satisfaction of using a product is one of the basis for consumers to believe the product. Accordingly, Ganesan (1994), Tax, Brown, Chandrashekaran (1998) and Aritonang R. (2016) showed that there is a relationship between satisfaction and trust.

From the theoretical basis and the researches it can be known that in addition to loyalty, another form of experience gained by consumers in buying or consuming a product is satisfaction with the product. Experience in the form of satisfaction would be one consideration of consumers to trust the product in the future. Based on such a framework it can be formulated hypothesis seven (H7) that satisfaction is a positive predictor of the trust.

\section{Trust as a Mediating Variable}

As described above, trust is a positive predictor of intention. In addition, loyalty, image and satisfaction is a positive predictor of trust and intentions. Based on such a framework, hypothesis eight (H8) can be formulated that relationships among loyalty, satisfaction and image with intention are mediated by trust.

Based on the above frameworks of thinking, a theoretical model of bank customers' intention can be visually presented in Figure 1.

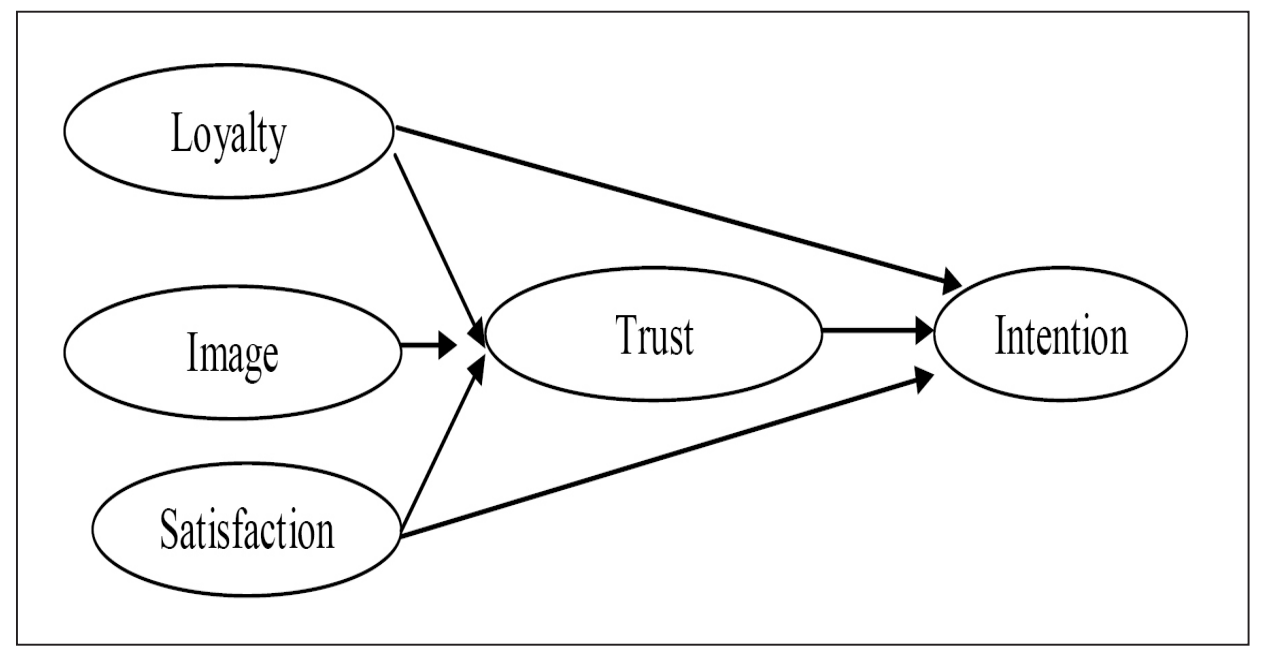

Figure 1. Theoritical Model of Bank Customers Intention

\section{RESEARCH METHOD}

\section{Sample}

The sample consists of 262 customers of five banks in Indonesia. The sample size is larger than the minimum requirement of using structural equation models, i.e. 200 (Boomsma, 1987 in Arbuckle, 1997). There are 117 men and 145 women. Their age ranges from 17 to 60 years, making an average of 26.5 years and a standard deviation of 4.9 years.

\section{Instruments}

All of this research variables are measured with a modified Likert scale with 10 alternative responses and the scores range from 1 to 10 (Allen and Rao, 2000). Options for the response range from strongly disagree to strongly agree with. The research instrument is presented in Table 2. 
Table 2. Instruments

Intention (Aritonang R., 2015)

1. Intention to continuously be a client of the bank

2. Probably to quit to other banks

3. Will be still a client of the bank

4. Motivation to be still a client of the bank

$$
\text { Trust (Aritonang R., 2015) }
$$

1. Bank's competence to realize its promises

2. Benevolence of the bank

3. Reliability of the bank's services

$$
\text { Loyalty (Aritonang R., 2015) }
$$

1. Years as a client

2. Proportion of using the bank's services

3. Frequencies of using the bank's services

$$
\text { Satisfaction (Aritonang R., 2015) }
$$

1. I am satisfied with the bank services

2. The bank services are unpleasant

3. The bank services are good

Image (Cengiz, Ayyildiz and Bünyamin, 2007)

1. Overall image

2. Relative image

3. People's opinion

\section{DATA ANALYSIS}

The data analysis in this research is Structural Equation Modeling by using LISREL (Linear Structural Relations) software.

\section{Goodness of Fit Statistics}

Goodness of fit statistics was used to assess measurement models and the structural model are Comparative Fit Index (CFI), Goodness of Fit Index (GFI), Adjusted Goodness of Fit Index (AGFI) and Root Mean Square Error of Approximation (RMSEA) (Joreskog and Sörbom, 1996; Bentler, 1990). The results are presented in Table 3 below:

Table 3. Goodness of Fit

\begin{tabular}{|l|c|}
\hline \multicolumn{1}{|c|}{ Statistics } & Results \\
\hline Chi-squared & 212,23 \\
\hline Degree of freedom (df) & 94 \\
\hline Significance & 0,00 \\
\hline Chi-squared / df & 2,26 \\
\hline RMSEA & 0.08 \\
\hline Significance & 0.00 \\
\hline CFI & 0,99 \\
\hline GFI & 0,91 \\
\hline AGFI & 0,90 \\
\hline
\end{tabular}

Table 3 shows that the chi-square significance $(0.00)$ is smaller than 0.05 so that the model is classified as not good
(Bagozzi and Yi, 1988). Accordingly, Jöreskog and Sörbom (1996) recommends a ratio between chi-square statistics and the degrees of freedom. The ratio (2.26) is big enough so that the model is classified as not good (Medsker, Williams, and Holahan, 1994). However, chi-square is actually not a good measure because it is very sensitive to the sample size. According to Bagozzi and Yi, 1988, the significant chi-square is not necessarily an indicator of a not good model.

Table 3 shows that the CFI $(0,99)$, GFI $(0,91)$ and AGFI $(0,90)$ are greater than 0,90 so that the model is quite good (Bagozzi and Yi, 1988). The statistics of RMSEA $(0,08$ with a significance of less than 0,05 ), which is smaller than the 0,10 , shows that the model is good enough (Browne and Cudeck, 1993 in Byrne, 1998). So, in general, the goodness of model fit is good that the assessment of the measurement and structural models may be continued even though the chi-square is not good (the significance is less than 0,05 ).

\section{Reliability and Validity}

Validity and reliability coefficients are presented in Table 4. Statistics of validities are classified as good, as shown by the standardized loadings which are greater than 0,2 (Chin, 1998) and significant (t-values $>1,96$ ). AVEs of each variable are greater than 0,5 so that the convergent validity of all

\begin{tabular}{|c|c|c|c|c|c|}
\hline Variable & $\begin{array}{l}\text { Standardized } \\
\text { Loadings }\end{array}$ & $\begin{array}{c}\mathrm{t}- \\
\text { values }\end{array}$ & AVE* & $\mathrm{R}^{2}$ & $\mathrm{CR}^{* *}$ \\
\hline $\begin{array}{l}\text { Intention } \\
\text { INT1 } \\
\text { INT2 } \\
\text { INT3 } \\
\text { INT4 }\end{array}$ & $\begin{array}{l}0,76 \\
0,83 \\
0,81 \\
0,80\end{array}$ & $\begin{array}{c}- \\
13,75 \\
13,47 \\
13,17\end{array}$ & 0,64 & $\begin{array}{l}0,58 \\
0,69 \\
0,66 \\
0,63\end{array}$ & 0,88 \\
\hline $\begin{array}{l}\text { Trust } \\
\text { TRU1 } \\
\text { TRU2 } \\
\text { TRU3 }\end{array}$ & $\begin{array}{l}0,83 \\
0,93 \\
0,85\end{array}$ & $\begin{array}{c}- \\
19,11 \\
16,80\end{array}$ & 0,76 & $\begin{array}{l}0,69 \\
0,96 \\
0,72\end{array}$ & 0,90 \\
\hline $\begin{array}{l}\text { Loyalty } \\
\text { LOY1 } \\
\text { LOY2 } \\
\text { LOY3 }\end{array}$ & $\begin{array}{l}0,90 \\
0,97 \\
0,79\end{array}$ & $\begin{array}{l}18,47 \\
20,96 \\
15,08\end{array}$ & 0,79 & $\begin{array}{l}0,81 \\
0,94 \\
0,62\end{array}$ & 0,92 \\
\hline $\begin{array}{l}\text { Satisfaction } \\
\text { SAT1 } \\
\text { SAT2 } \\
\text { SAT3 }\end{array}$ & $\begin{array}{l}0,83 \\
0,77 \\
0,89\end{array}$ & $\begin{array}{l}15,81 \\
14,11 \\
17,61\end{array}$ & 0,69 & $\begin{array}{l}0,68 \\
0,59 \\
0,78\end{array}$ & 0,87 \\
\hline $\begin{array}{l}\text { Image } \\
\text { IMA1 } \\
\text { IMA2 } \\
\text { IMA3 }\end{array}$ & $\begin{array}{l}0,70 \\
0,82 \\
0,87\end{array}$ & $\begin{array}{l}12,53 \\
15,67 \\
17,19\end{array}$ & 0,64 & $\begin{array}{l}0,49 \\
0,67 \\
0,76\end{array}$ & 0,84 \\
\hline
\end{tabular}
variables are classified as good (Fornell and Larcker, 1981).

Table 4. Measurement Model Statistics

Table 4 shows that all of the items have good reliabilities, as demonstrated by the $\mathrm{R}^{2}$ statistics which are greater than 0,4 
(Bagozzi and Baumgartner, 1994). All variables have good reliabilities (CR), as shown by the CR statistics which are greater than 0,7 (Fornell and Larcker, 1981).

Evaluation of discriminant validity of all variables is based on

Table 5. Discriminant Validity of Variables statistics presented in Table 5. AVEs of all variable are greater than its coefficient determination and other variables. Thus, the discriminant validity of all variables is good (Fornell and Larcker, 1981).

\begin{tabular}{|l|c|c|c|c|c|l|}
\hline \multirow{2}{*}{ Variables } & \multicolumn{2}{|l|}{ AVE } & \multicolumn{5}{|c|}{ Coefficients of Determination $\left(\mathrm{R}^{2}\right)$} \\
\cline { 3 - 8 } & & Intention & Trust & Loyalty & Satisfaction & Image \\
\hline Intention & 0,64 & - & 0,63 & 0,44 & 0,37 & 0,38 \\
\hline Trust & 0,76 & 0,63 & - & 0,52 & 0,48 & 0,48 \\
\hline Loyalty & 0,79 & 0,44 & 0,52 & - & 0,31 & 0,44 \\
\hline Satisfaction & 0,69 & 0,37 & 0,48 & 0,31 & - & 0,52 \\
\hline Image & 0,64 & 0,38 & 0,48 & 0,44 & 0,52 & - \\
\hline
\end{tabular}

Based on the evaluation of the reliability and validity of measurement models, evaluation of the structural model may be continued.

\section{RESULTS}

Empirical test results of the structural model are presented in Figure 2 (t-value) and Table 6. All of the seven path coefficients are positive and significant ( $t$-values are greater then 1,96). The direct effect of trust on intention is 0,64 ( $t$-value $=10,60)$. The direct effect is the same as its total effect because there is no mediator variable between trust and intention. Sign of the coefficient, i.e. positive, is consistent with the sign in H1. Moreover, the direct effect is significant.

The direct effect of loyalty on intention is 0,14 ( $\mathrm{t}$-value $=$ $2,61)$. Sign of the effect, i.e. positive, is consistent with the sign in H2. In addition, the direct effect is significant because the t-value is greater than 1.96 .

The direct effect of satisfaction on intention is 0,05 ( $t$-value $=0,86)$. Sign of the effect, i.e. positive, is consistent with the sign in H3. In addition, the direct effect is not significant because the $t$-value is less than 1.96 .

The direct effect of image on intention is 0,05 ( $t$-value $=0,88$ ). Sign of the effect, i.e. positive, is consistent with the sign in H4. In addition, the direct effect is not significant because the $\mathrm{t}$-value is less than 1.96 .

The direct effect of loyalty on trust is 0,42 ( $t$-value $=8,44$ ). Sign of the effect, i.e. positive, is consistent with the sign in $H 5$. In addition, the effect is significant because the $t$-value is

Table 6. Effect: Total (ET), Direct (DE), and Indirect (IE) greater than 1.96. The direct effect and total effect of loyalty on trust are the same because there is no mediator variable between these two variables.

The direct effect of image on trust is 0,16 ( $\mathrm{t}$-value $=2,63$ ). Sign of the effect, i.e. positive, is consistent with the sign in H6. In addition, the direct effect is significant because the t-value is greater than 1.96. The direct effect and the total effect of satisfaction on trust are the same because there is no mediator variable between these two variables.

The direct effect of satisfaction on trust is 0,34 ( $\mathrm{t}$-value $=$ $6,29)$. Sign of the effect, i.e. positive, is consistent with the sign in H7. In addition, the direct effect is significant because the $t$-value is greater than 1.96. The direct effect and the total effect of satisfaction on trust is the same because there is no mediator between these two variables.

The total effect of trust on intention is 0,64 ( $t$-value $=10,60$ ) and there is no indirect effect because there is no mediating variable. The effect is significant because the t-value is greater than 1.96.

The total effect of loyalty on intention is equal to 0,41 ( $\mathrm{t}$-value $=7,12$ ) consisting of a direct effect of 0,14 ( $t$-value $=2,61$ ) and the indirect effect of 0,27 ( $t$-value $=6,60$ ). Thus, the direct effect of loyalty on intention is smaller than the indirect effect of loyalty - through trust - on intention. In addition, the direct and indirect effect are significant. It means that trust has a significant partial mediation role on the relationship between loyalty and intention. It is consistent with H8.

\begin{tabular}{|c|c|c|c|c|c|}
\hline & \multicolumn{3}{|c|}{ Intention } & \multicolumn{2}{|c|}{ Trust } \\
\hline & ET & $\mathrm{DE}$ & IE & ET & $\mathrm{DE}$ \\
\hline Trust & $\begin{array}{c}0,64 \\
(10,60)\end{array}$ & $\begin{array}{c}0,64 \\
(10,60)\end{array}$ & & & \\
\hline Loyalty & $\begin{array}{c}0,41 \\
(7,12)\end{array}$ & $\begin{array}{c}0,14 \\
(2,61)\end{array}$ & $\begin{array}{c}0,27 \\
(6,60)\end{array}$ & $\begin{array}{c}0,42 \\
(8,44)\end{array}$ & $\begin{array}{c}0,42 \\
(8,44)\end{array}$ \\
\hline Satisfaction & $\begin{array}{c}0,27 \\
(4,24)\end{array}$ & $\begin{array}{c}0,05 \\
(0,86)\end{array}$ & $\begin{array}{c}0,22 \\
(5,41)\end{array}$ & $\begin{array}{c}0,34 \\
(6,29)\end{array}$ & $\begin{array}{c}0,34 \\
(6,29)\end{array}$ \\
\hline Image & $\begin{array}{c}0,15 \\
(2,20)\end{array}$ & $\begin{array}{c}0,05 \\
(0,88)\end{array}$ & $\begin{array}{c}0,10 \\
(2,55)\end{array}$ & $\begin{array}{c}0,16 \\
(2,63)\end{array}$ & $\begin{array}{c}0,16 \\
(2,63)\end{array}$ \\
\hline \multicolumn{6}{|c|}{ (t-value) } \\
\hline
\end{tabular}




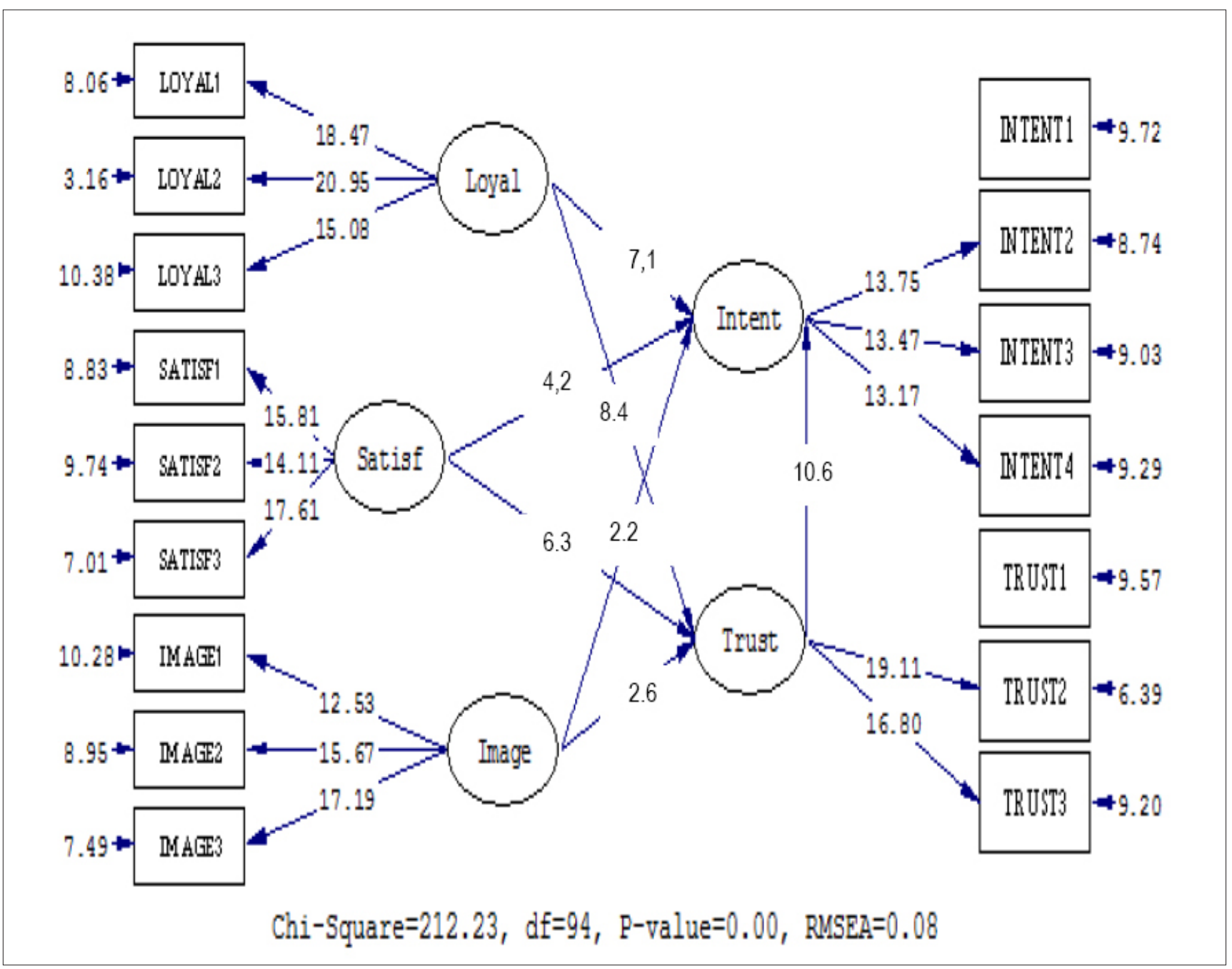

Figure 2. Empirical Model of Bank Clients' Intention

The total effect of satisfaction on intention is equal to 0,27 ( $\mathrm{t}$-value $=4,24$ ) consisting of a direct effect of 0,05 (t-value $=0,86$ ) and the indirect effect of 0,22 ( $t$-value $=5,41$ ). Thus, the direct effect of satisfaction on intention is smaller than the indirect effect of loyalty - through trust - on intention. In addition, the direct and indirect effect are significant. It means that trust has a significant partial mediation role on the relationship between satisfaction and intention. It is consistent with H8.

The total effect of image on intention is equal to 0,15 ( $t$-value $=2,20$ ) consisting of a direct effect of 0,05 ( $t$-value $=0,88$ ) and the indirect effect of 0,10 ( $t$-value $=2,55$ ). Thus, the direct effect of image on intention is smaller than the indirect effect of loyalty - through trust - on intention. In addition, the direct effect is not significant but the indirect effect is significant. It means that trust has a significant partial mediation role on the relationship between image and intention. It is consistent with H8.

The multiple correlation coefficient between intention with trust, loyalty, image and satisfaction is 0,67 and the determination coefficient is 0,45 . It means that only $45 \%$ of intention variation can be explained by variations in trust, loyalty, image and satisfaction. Fifty five percent of the intention variation cannot be explained by variations in trust, loyalty, image and satisfaction. In other words, there are other variables that may be included in the research model so that more intention variations can be explained.

The multiple correlation coefficient between trust with loyalty, image and satisfaction is 0,65 and the determination coefficient is 0,42 . It means that only $42 \%$ of trust variation can be explained by variations in loyalty, image and satisfaction. Sixty eight percent of the variation cannot be explained by variations in loyalty, image and satisfaction. In other words, there are other variables that may be included in the research model so that more trust variations can be explained.

\section{DISCUSSIONS}

Based on the theory and relevant researches and through the frame of thinking about this research, eight hypotheses have been formulated. Hypothesis one (H1) has empirically proved that trust has a direct positive and significant effect on intention. This is consistent with the theory as the basis for formulating H1 (Fishbein and Ajzen, 1975; Ajzen, 1991) 
as well as the previous relevant researches (Aritonang R., 2016).

Loyalty has a positive and significant total effect directly and indirectly on intention, as formulated in hypothesis two (H2). It is consistent with the previous relevant researches (Chinomona and Sandada, 2013; Fandos and Flavian, 2006; Hsin, Huery and Yes, 2009; Schoenbachler, Gordon and Aurand, 2004; Aritonang R., 2015).

Image has a positive effect on intention, as formulated in hypothesis three (H3). It is consistent with the previous researches (Zeithaml, 1988; Selnes, 1993; Zins, 2001; Cretu and Brodie, 2007; Thakur and Singh, 2012; Che-Hui, MiinJye, Li-Ching and Kuo-Lung, 2015; Cretu and Brodie, 2007; Sondoh Jr., Omar, Wahid, Ismail, Ishak and Harun, 2007).

Satisfaction has a positive effect on intention, as formulated in hypothesis three (H4). It is consistent with the previous researches (Martin, O'Neil, Hubbard and Palmer, 2008; Deng, Turner and Prince, 2010; Rejikumar and Ravindran, 2012; Lee, Trail, Lee and Schoenstedt, 2013; Keng and Liao, 2009).

The effect of loyalty on trust as formulated in hypothesis five (H5) was empirically tested and the effect is significant. It is consistent with the previous researches (Ganesan, 1994; Tax, Brown and Chandrashekaran, 1998; Kim and Ghantous, 2013; Aritonang R., 2015).

The effect of image on trust as formulated in hypothesis six (H6) was empirically tested and the effect is significant. It is consistent with the previous researches (Che-Hui, Miin-Jye, Li-Ching and-Lung Kuo, 2015).

The effect of satisfaction on trust as formulated in hypothesis seven (H7) was empirically tested and the effect is significant. It is consistent with the previous researches (Ganesan, 1994; Tax, Brown, Chandrashekaran, 1998).

The empirical testing of $\mathrm{H} 2$ showed that loyalty has a positive and significant total effect directly and indirectly on intention. Accordingly, the test results on hypothesis eight showed that the direct effect is smaller than the indirect effect. It is consistent with the frame of thinking for H8.

The empirical testing of $\mathrm{H} 3$ and $\mathrm{H} 4$ showed that image and satisfaction have a positive direct effect, but not significant, on intention. Accordingly, the test results on hypothesis eight showed that image and satisfaction have an indirect positive and significant effect - through trust - on intention. It means that trust has a partial mediating role on loyalty and satisfaction with intention. It is consistent with the frame of thinking for $\mathrm{H8}$.

\section{LIMITATIONS AND FUTURE RESEARCHES}

The subjects of this research are bank customers in two campuses in West Jakarta. Generalizing these results, of course, are limited to existing customers on both campuses. Accordingly, it is important to use other banks so that the generalization of the results increases. In addition, an application of this research model to other services is important, such as insurance companies. Thus, generalization of the model may increase.

The coefficient of determination of intention is 0,45 whereas the coefficient of determination of trust is 0,42 . Adding other relevant variables to intention and trust will increase both coefficient determinations. The other variables could be cognitive dissonance (Kessler, 2010), gender, length of time as bank customers, the number of banks used and relatives who become customers of the same bank.

\section{REFERENCES}

1. Aaker, D. A. and Joachimsthaler, E. (2000), Brand Leadership, The Free Press, New York.

2. Ajzen, Icek (1991), "Theory of planned behavior", Organizational Behavior and Human Decision Processes, Vol. 50, pp. 179-211.

3. Allen, C. T., Machleit, K. A. and Kleine, S. S. (1992), "A comparison of attitudes and emotions as predictors of behaviour at diverse levels of behavioral experience", Journal of Consumer Research, Vol. 18 No. 4, pp. 493-504.

4. Allen, D. R. and Rao, T. R. (2000), Analysis of customer Satisfaction Data, ASQ Quality Press, Milwaukee, Wisconsin.

5. AMA (2007). Definition of Brand (AMA Dictionary) [Online] Available: http://www.marketingpower.com/_ layouts/Dictionary.aspx?dLetter $=B$

6. Anderson, J. C. and Narus, J. A. (1990), "A model of distributor firm and manufacturer firm working partnerships", Journal of Marketing, Vol. 54 January, pp. 42-58.

7. Anuwichanont, J. (2011), "The impact of price perception on customer loyalty in the airline context", Journal of Business and Economics Research, Vol. 9 No. 9, pp. 37-49.

8. Arbuckle, J. L. (1997), Amos User's Guide Version 3.6, SmallWaters Corporation, Chicago, IL.

9. Aritonang R., Lerbin R. (2015), "Initial model of behavioral loyalty in banking context", Research report, LPPI Tarumanagara University, Jakarta.

10. Arora, Raj (1996), "Influence of price and variety of services on consumer intention to use the services: an experimental investigation", Journal of Professional Services Marketing, Vol. 15 No. 1, pp. 105-120.

11. Bagozzi, R. and Baumgartner, H. (1994), "The evaluation of structural equation models and hypothesis testing", Principles of Marketing Research, R. Bagozzi (Ed.), Cambridge, pp. 386-422.

12. ___ and Yi, Y. (1988), "On the evaluation on structural equation models", Journal of the Academy of Marketing Science, Vol. 16 No. 1, pp. 74-94. 
13. Ball, D., Coelho, P. and Machas, A. (2004), "The role of communication and trust in explaining customer loyalty: an extension to the EXSI model", European Journal of Marketing, Vol. 38 No. 9/10, pp. 1272-1293.

14. Barsky, J. and Nash, L. (2002), "Evoking emotion: affective keys to hotel loyalty", Cornell Hotel and Restaurant Administration Quarterly, Vol. 43 February, pp. 39-46.

15. Benachenhouand, S. M. and Benhabib, A. (2013), “Testing customer brand loyalty on a mobile telephone company in Algeria: applying the structural equation modelling", Acta de Gerencia Ciencia, Vol. 1 No. 3, pp. 28-40.

16. Bentler, P. M. (1990), "Comparative fit indexes in structural models”, Psychological Bulletin, Vol. 197 No. 2, pp. 238-46.

17. Bravo, Rafael, Montaner, Teresa and Pina, Jose M. (2012), "Corporate brand image of financial institutions: a consumer approach", Journal of Product and Brand Management, Vol. 21 No. 4, pp. 232-245.

18. Byrne, B. M. (1998), "Structural equation modeling with LISREL, PRELIS, and SIMPLIS: Basic concepts, applications, and programming, Lawrence Erlbaum Associates, Publishers, Mahwah, New Jersey.

19. Caceres, R. C. and Paparoidamis, N. G. (2007), "Service quality, relationship satisfaction, trust, commitment and business-to-business loyalty", European Journal of Marketing, Vol. 41, pp. 836-867.

20. Cadotte, Ernest R., Woodruff, Robert B., and Jenkins, Roger L. (1987), "Expectations and norms in models of consumer satisfaction", Journal of marketing Research, Vol. 24 No. 3, pp. 305-314.

21. Carter, M., Wright, R., Thatcher, J. B. and Klein, R., (2014), 'Understanding online customers' ties to merchants: the moderating influence of trust on the relationship between switching costs and e-loyalty", European Journal of Information Systems, Vol. 23, pp. 185-204.

22. Casalo, L., Flavián, C. and Guinalíu, M. (2008), “The role of satisfaction and website usability in developing customer loyalty and positive word-of-mouth in the e-banking services", The International Journal of Bank Marketing, Vol. 26 No. 6, pp. 399-417.

23. Cengíz, E., Ayyildiz, H. and Bünyamin ER (2007), “Effects of image and advertising efficiency on customer loyalty and antecedents of loyalty: Turkish banks sample", Banks and Bank systems, Vol. 2 No. 1, pp. 56-71.

24. Chin, W. (1998), "Issues and opinions on structural equation modelling. MIS Quarterly, Vol. 22 No. 1, pp. 7-16.

25. Chinomona, Richard and Sandada, Maxwell (2013), "The influence of market related mobile activities on the acceptance of mobile marketing and consumer intention to purchase products promoted by SMS in South Africa", The Journal of Applied Business Research, Vol. 29 No. 6, pp. 1897-1908.

26. Cyr, D., Hassanein, K., Head, M. and Ivanov, A. (2007), "The role of social presence in establishing loyalty in e-service environments", International Journal of HumanComputer Studies, Vol. 67 No. 10, pp. 850-869.

27. Delgado-Ballester, E. and Munuera-Aleman, J. L. (2001), "Brand trust in the context of consumer loyalty", European Journal of Marketing, Vol. 35 No. 11/12, pp. 1238-1258.

28. Deng, L., Turner, D. E., Gehling, R. and Prince, B. (2010), "User experience, satisfaction, and continual usage intention of IT", European Journal of Information Systems, Vol. 19, pp. 60-75.

29. dos Santos, C. P. and Basso, K. (2012), "Do ongoing relationships buffer the effects of service recovery on customers' trust and loyalty? ", International Journal of Bank Marketing, Vol. 30 No. 3, pp. 168-192.

30. Engel, James F., Roger D. Blackwell and Paul W. Miniar (1995), Consumer Behavior. The Dryden Press, New York.

31. Fandos, C. and Flavián, C. (2006), "Intrinsic and extrinsic quality attributes, loyalty and buying intention: an analysis for a PDO", British Food Journal, Vol. 108 No. 8, pp. 646-662.

32. Fishbein, M. and Ajzen, I. (1975), Belief, Attitude, Intention and Behaviour: An introduction to theory and research, Addidison-Wesley Publishing Company Reading, Massachusetts.

33. Fombrun, C. and Shanley, M. (1990), "What's in a name? Reputation building and corporate strategy", Academy of Management Journal, Vol. 33 No. 2, pp. 233-258.

34. Fornell, C. and Larcker, D. F. (1981), "Evaluating structural equation models with unobservables and measurement error", Journal of Marketing Research, Vol. 18 No. 1, pp. 39-50.

35. Ganesan, Shankar (1994), "Determinants of long-term orientation in buyer-seller relationships", Journal of Marketing, Vol. 58 April, pp. 1-19.

36. Garbarino, E. and Johnson, M. S. (1999), "The different roles of satisfaction, trust, and commitment in consumer relationship", Journal of Marketing, Vol. 63 April, pp. 7087.

37. Geok, T. L. and Sook, H. L. (1999), “Consumers' trust in a brand and the link to brand loyalty", Journal of Market Focused Management, Vol. 4 No. 4, pp. 341-370.

38. Gryna, Frank M. (2001), Quality Planning and Analysis. From product development through use, McGraw-Hill Irwin, New York. 
39. Herbst, Kenneth, Hannah, Sean T. and Allan, David (2013), "Advertisement disclaimer speed and corporate social responsibility: 'Cost' to consumer comprehension and effects on brand trust and purchase intention", Journal of Business Ethics, Vol. 117, pp. 297-311.

40. Hill, Nigel and Alexander, Jim (2000), Handbook of Customer Satisfaction and Loyalty Measurement, Gower Publishing Limited, England.

41. Hoffmann, Arvid O. I., Franken, Heiner, Broekhuizen, Thijs L. J. (2012), "Customer intention to adopt a feebased advisory model. An empirical study in retail banking", International Journal of Bank Marketing, Vol. 30 No. 2, pp. 102-127.

42. Holbrook, Morris B. and Hirschman, Elizabeth C. (1982), "The experiential aspects of consumption: consumer fantasies, feelings, and fun", Journal of Consumer Research, Vol. 9 No. 2, pp. 132-140.

43. Horppu, M., Kuivalainen, O., Tarkiainen, A. and Ellonen, H-K. (2008), "Online satisfaction, trust and loyalty, and the impact of the offline parent brand", Journal of Product and Brand Management, Vol. 17 No. 6, pp. 403-413.

44. Hsin K. C., Huery R. Y. and Ya T. Y. (2009), "The impact of brand awareness on consumer purchase intention: the mediating effect of perceived quality and brand loyalty", The Journal of International Management Studies, Vol. 4 No. 1, pp. 135-144.

45. Jöreskog, K. and Sörbom, D. (1996), LISREL 8: User's Reference Guide, IL: Scientific Software International, Inc., Chicago.

46. Jones, T. and Taylor, S. F. (2007), "The conceptual domain of service loyalty: How many dimensions?", Journal of Services Marketing, Vol. 21 No. 1, pp. 36-51.

47. Keng, Ching-Jui and Liao, Tze-Hsien (2009), "Consequences of postpurchase dissonance: the mediating role of an external information search", Social Behavior and Personality, Vol. 37 No. 10, pp. 1327-1339.

48. Kim, N. P. and Ghantous, N. (2013), "Managing brand associations to drive customers' trust and loyalty on Vietnamese banking", International Journal of Bank Marketing, Vol. 31 No. 6, pp. 456-480.

49. Lee, Donghun, Trail, Galen T., Lee, Cindy and Schoenstedt, Linda J. (2013), "Exploring factors that affect purchase intention of athletic team merchandise", Journal of Research, Vol. 8 No. 1, pp. 40-48.

50. Liu, Chin-Hung (2015), "The impact on switching intention of e-trading systems for the securities industry", Global Journal of Business Research, Vol. 9 No. 1, pp. 75-88.

51. Loudon, David L. and Bitta, Albert J. Della (1993), Consumer Behavior, McGraw-Hill, Inc., New York.
52. Mahmoudzadeh, S. M., Bakhshanden, G. and Ilkhechi, M. S. (2013), "Exploring the effect of brand identity on purchase intention in cell phone market in Iran", International Journal of Management and Humanity Sciences, Vol. 2 S, pp. 1165-1173.

53. Maiyaki, Ahmed Audu (2013), "Moderating effect of individualism/collectivism on the association between service quality, corporate reputation, perceived value and consumer behavioral intention", Journal of Marketing and Management, Vol. 4 No. 1, pp. 1-20.

54. Martin, David, O’Neill, Martin, Hubbard, Susan and Palmer, Adrian (2008), "The role of emotion in explaining consumer satisfaction and future behavioral intention", Journal of Services Marketing, Vol. 22 No. 3, pp. 224-236.

55. Matzler, K., Grabner-Krauter, S. and Bidmon, S. (2006), "Individual determinants of brand affect: the role of the personality traits of extraversion and openness to experience", Journal of Product and Brand Management, Vol. 15 No. 7, pp. 427-434.

56. Medsker, G. J., Williams, L. J. and Holahan, P. J. (1994), "A review of current practices for evaluating causal models in organizational behavior and human resource management research", Journal of Management, Vol. 20 No. 2, pp. 439-64.

57. Moorman, C., Zaltman, G. and Deshpande, R. (1992), "Relationships between providers and users of market research: the dynamics of trust within and between organizations", Journal of Marketing Research, Vol. 29 August, pp. 314-29.

58. Morgan, R. M. and Hunt, S. D. (1994), "The commitmenttrust theory of marketing relationship", Journal of Marketing, Vol. 58 July, pp. 20-38.

59. Neal, W. D. (1998), "Satisfaction be damned, value drives choice", Advertising Research Foundation Week of Workshops.

60. __ (1999), "Satisfaction is nice, but value drives loyalty. The most satisfied customer may not necessarily be the most loyal", Marketing Research, Vol. 11 No. 1, pp. 20-23.

61. _ (2000), "For most customers, loyalty isn't an attitude", Marketing News, Vol. 4 No. 8, p. 7.

62. Oliver, Richard L. (1993), "Cognitive, affective, and attribute bases of the satisfaction response", Journal of Consumer Research, Vol. 20 No. 3, pp. 418-30.

63. _ (1997), Satisfaction. A behavioral perspective on the consumer, The McGraw-Hill Companies, Inc., New York.

64. __ (1999), "Whence consumer loyalty", Journal of Marketing, Vol. 63 Special Issue, pp. 33-44.

65. O’Malley, L. (1998), “Can loyalty schemes really build loyalty?", Marketing Intelligence and Planning, Vol. 16 No. 1, pp. 47-55. 
66. Page, Carole and Luding, Ye (2003), "Bank managers' direct marketing dilemmas - customers's attitudes and purchase intention", The International Journal of Bank Marketing, Vol. 21 No. 2/3, pp. 147-163.

67. Puschel, Julio and Mazzon, Jose Afonso (2010), “Mobile banking: proposition of an integrated adoption intention framework", International Journal of Bank Marketing, Vol. 28 No. 5, pp. 389-409.

68. Ramaseshan, B., Rabbanee, F. K. and Hui, L. T. H. (2013), "Effects of customer equity drivers on customer loyalty in B2B context", Journal of Business and Industrial Marketing, Vol. 28 No. 4, pp. 335-346.

69. Rejikumar, G. and Ravindran, D. S. (2012), "An empirical study on service quality perceptions and continuance intention in mobile banking context in India", Journal of Internet Banking and Commerce, Vol. 17 No. 1, pp. 1-22.

70. Reichheld, F. F. and Sasser, W. E., Jr. (1990), "Zero defections: quality comes to services", Harvard Business Review, Vol. 68 No. 5, pp. 105-111.

71. Richins, M. L. (1997), "Measuring emotions in the consumption experience", Journal of Consumer Research, Vol. 24 No. 2, pp. 127-47.

72. Rotter, A. B. (1967). A new scale for the measurement of interpersonal trust", Journal of Personality, Vol. 35 No. 4, pp. 651-665.

73. Schoenbachler, D. D., Gordon, G. L. and Aurand, T. W. (2004), "Building brand loyalty through individual stock ownership", The Journal of Product and Brand Management, Vol. 13 No. 7, pp. 488-497.

74. Shainesh, G. (2012), "Effects of trustworthiness and trust on loyalty intentions. Validating a parsimonious model in banking", International Journal of Bank Marketing, Vol. 30 No. 4, pp. 267-279.

75. Sharifi, S. S. and Esfiandi, M. S. (2014), "The impacts of relationship marketing on cognitive dissonance, satisfaction, and loyalty. The mediating role of trust and cognitive dissonance", International Journal of Bank Marketing, Vol. 42 No. 6, pp. 553-575.

76. Sheth, J. N. and Mittal, B. (2004), Customer Behavior: a Managerial Perspective, Thomson, South-Western, Australia.
77. Singh, J. J., Iglesis, 0. and Batista-Foguet, J. M. (2012), "Does having an ethical brand matter? The influence of consumer perceived ethicality on trust, affect and loyalty", Journal of Business Ethics, Vol. 111, pp. 541549.

78. Sumaedi, S., et al. (2014), "The role of trust, perceived value, and satisfaction (a case study from Bekasi, Indonesia) ", Clinical Governance: An International Journal, Vol. 19 No. 3, pp. 1477-7274.

79. Tax, Stephen S., Brown, Stephen W. and Chandrashekaran, Murali (1998), "Customer evaluations of service complaint experiences: Implications for relationship marketing", Journal of Marketing, Vol. 62 Iss. 2, pp. 6076.

80. Topcu, Bunyamin and Duygun A. (2015), "The impact of customer loyalty on negative word-of-mouth communication and repurchase intention", Journal of Marketing and Management, Vol. 6 No. 1, pp. 16-27.

81. Tsai, Huei-Ting, Chien, Jui-Lin and Tsai, Ming-Tien (2014), "The influence of system usability and user satisfaction on continued internet banking services usage intention: empirical evidence from Taiwan", Electron Commer Res, Vol. 14, pp. 137-169.

82. Tsiotsou, R. H. (2013), "Sport team loyalty: integrating relationship marketing and a hierarchy of effects", Journal of Services Marketing, Vol. 27 No. 6, pp. 458-471.

83. Upamannyu, N. K., Gulati, C. and Mathur, G. (2014), "Effect of brand trust, brand image on costumer brand loyalty in FMCG sector at Gwalior Region", Scholars World-IRMJCR, Vol. II No. II, pp. 83-93.

84. Wells, William D. and Prensky, David (1996), Consumer Behavior, John Wiley and Sons., New York.

85. Zeithaml, V. A. (2000), "Service quality, profitability, and the economic worth of customers: what we know and what we need to learn", Journal of the Academy of Marketing Science, Vol. 28 No. 1, pp. 67-85.

86. Zeithaml, V. A., Berry, L. L. and Parasuraman, A. (1996), "The behavioural consequences of service quality", Journal of Marketing, Vol. 60 No. 2, pp. 31-46.

Citation: Lerbin R. Aritonang R., "Relationships among Loyalty, Image, Satisfaction and Intention Mediated by Trust", American Research Journal of Business and Management, Vol 7, no. 1, 2021, pp. 1-12.

Copyright (C) 2021 Lerbin R. Aritonang R., This is an open access article distributed under the Creative Commons Attribution License, which permits unrestricted use, distribution, and reproduction in any medium, provided the original work is properly cited. 